\title{
Exploring the relationship among local conflicts and territorial vulnerability: The case study of Lombardy Region
}

\author{
Alessandra Oppio ${ }^{a}$, Stafano Corsi ${ }^{b, *}$, Sergio Mattia ${ }^{a}$, Andrea Tosini ${ }^{b}$ \\ a Department of Architecture and Urban Studies (DAStU), Politecnico di Milano, via Bonardi 3, 20133 Milan, Italy \\ ${ }^{\mathrm{b}}$ Department of Economics, Management, and Quantitative Methods (DEMM), University of Milan, via Celoria 2, 20133 Milan, Italy
}

\section{A R T I C L E I N F O}

\section{Article history:}

Received 10 January 2014

Received in revised form 31 October 2014

Accepted 10 November 2014

\section{Keywords:}

Vulnerability assessment

Local conflicts

Overlay mapping

Lombardy region

\begin{abstract}
A B S T R A C T
During the last 10 years, opposition by local communities against the development of industrial facilities, energy technologies and transport infrastructures has steadily grown. Negative externalities on the environment, quality of life and health are the most frequent motivations of the opponents. Disputes are typically grounded in environmental, social and economic concerns about the local impacts of new development proposals. Within this context, this paper aims to explore the existence of a potential relationship between the level of territorial vulnerability and the distribution of local conflicts surveyed by the local and national press in the Lombardy Region (Italy). This type of relationship is investigated using an empirical analysis based on an overlay mapping of different informative layers. The vulnerability index has been calculated according to the most recent conceptual and analytical frameworks developed in the scientific literature. It is a multidimensional index grounded in environmental, social and economic criteria. The outputs of the vulnerability assessment have been placed into thematic maps to provide a comprehensive overview of the environmental and socioeconomic state of the Lombardy Region. In addition to the general degree of vulnerability, the maps display the local conflicts surveyed by the NIMBY Forum, an Italian survey of territorial disputes managed by the Agency of Research and Information Society. The maps provide a means of i) putting forward some hypotheses about the oppositions that have emerged around the localization of new facilities, including mainly industrial facilities, waste disposals, energy plants and transport infrastructures, and the vulnerability of the Lombardy Region; ii) identifying the driving factors of territorial vulnerability; iii) investigating whether the local oppositions are directly proportional to territorial vulnerability. The first results indicate that a direct relationship among territorial vulnerability and conflicts does not exist. This outcome, even on a preliminary basis, provides a new analytical perspective for understanding the reasons behind local community protests.
\end{abstract}

(c) 2014 Elsevier Ltd. All rights reserved.

\section{Introduction}

The study of various interactions between people that are the result of concerns for environmental quality is a field of research that has been comprehensively investigated since the second half of the last century; this is the result of the growing public awareness of the negative externalities of human action on the natural landscape. As many scholars have claimed, no economic activity is exempt from externalities (Pigou, 1948; Mishan, 1965; Boulding, 1966; Barde and Gerelli, 1980; Roegen, 1971).

Thus, many theoretical perspectives and methodological approaches for understanding, evaluating and providing options

\footnotetext{
* Corresponding author. Tel.: +39 3403770163.

E-mail addresses: alessandra.oppio@polimi.it (A. Oppio), stefano.corsi@unimi.it(S. Corsi).
}

for land use to ensure that human habitation adheres to sustainability principles have been developed (Ndubisi, 2002). The most relevant threat to these goals is the loss in the ecological value of environmental resources and the resulting decrease in human well-being. Environmental and socio-economic vulnerability is too often neglected in decisions regarding territorial and/or urban redevelopment interventions, as indicated by the amount of local community opposition against facilities that are perceived as a danger (Mattia and Oppio, 2008). The opposition of local communities to new infrastructures and plants, the so-called NIMBY (Not In My Back Yard) syndrome, are considered a proxy indicator of the level of the perceived risk. Many scholars have examined the causes of local conflicts in different fields such as urbanization in agrarian landscapes (Darly and Torre, 2013; Torre et al., 2014), the committee against extractive industry (Hilson, 2002), and the interferences between wind power and military aviation (Lindgren et al., 2013). Others have provided suggestions for land use conflict resolution 
based for the most part on community involvement in decisionmaking processes (Rauschmayer and Wittmer, 2006; Wittmer et al., 2006; Nijnik et al., 2009; Hessel et al., 2009; Kamruzzaman and Baker, 2013; Magsi and Torre, 2013; Saarikoskia et al., 2013).

The potential negative impact of infrastructure and plants on the environmental, economic and social systems should be considered a further pressure factor (Bradley and Smith, 2004), especially for those territories that are highly vulnerable as a consequence of their susceptibility to harm or hazard (Menoni et al., 2011) or to their inability to cope with external events (Cutter et al., 2003; Turner et al., 2003; Berry et al., 2006; Metzger et al., 2006; Smith et al., 2008).

Changes in land use, socio-economic characteristics, biodiversity, atmospheric composition and climate reduce the capability of a territory that is meant to be an ecosystem that provides vital services for people and society such as biodiversity, food, fibre, water resources, carbon sequestration and recreation (Costanza et al., 1997; De Groot et al., 2002).

Within this context, the concept of vulnerability has been increasingly considered, as it reveals the degree to which a territorial system is likely to experience harm due to different types of threats, and the goal has been to provide reliable information for policy and decision making (Golobič and Breskvar Žaucery, 2010). Furthermore, vulnerability is the susceptibility of a given population, system, or place to harm from exposure to the hazard, and it directly affects the ability to prepare for, respond to, and recover from hazards and disasters (Cutter et al., 2009). On the one hand, it focuses on the state of a territory described by a specific set of criteria. On the other hand, it also refers to how the natural and human environment can respond to external events (Toro et al., 2011) that have the potential to become worse (Bradley and Smith, 2004). According to the ecosystem approach (Millenium Ecosystem Assessment, 2005), vulnerability is a multidimensional notion, as it regards not only the environmental and physical issues but also the systemic, social/community/institutional and economic ones and their relationship (Cutter et al., 2003; Menoni et al., 2012).

The vulnerability of the territory with respect to the realization of infrastructures can also be associated with land consumption and the impact on the agricultural system (Mazzocchi et al., 2013; Torre et al., 2014). Because this notion has been studied in several fields, many complementary definitions have been developed according to different conceptual models and frameworks with different methods of measurement (Tran et al., 2010).

Although the many definitions of the notion of vulnerability highlight the different faces of the same concept, they all focus on the following concepts: $i$ ) vulnerability is an intrinsic feature of a system that can be described by the use of a specific set of criteria; ii) the notion of vulnerability is multidimensional as it affects not only the environmental aspect of a territory but also the economic and social ones and their mutual relationships.

The definitions of risk are several. The definition used in the Legislative Decree no. 81 of 2008, which follows the one proposed by Cutter (Cutter et al., 2000), defines "risk" as the product of the level of damage in the conditions of use and the frequency of adverse events (D.Lgs No. 81 of 2008, Article 2). The definition conforms to the following formula:

$R=D * F$

where $R$ represents the risk, $D$ for damage and $F$ for the frequency of harmful events; the territorial vulnerability could affect both the frequency and the level of harm. The development of infrastructure in a vulnerable context strengthens the risk, as it increases the frequency and the significance of the harmful events. Thus, the risk $(R)$ should be commensurate to the degree of territorial vulnerability (V):

\section{$R \sim V$}

At the same time, the conflicts $(C)$ should be proportional to the risk, as the local communities generally hinder the development of interventions perceived as dangerous:

\section{$C \sim R$}

Consequently, the level of disputes against facilities should be balanced with the degree of territorial vulnerability:

\section{$C \sim V$}

Starting from this conceptual framework, the paper aims to explore the existence of a potential relationship between the level of territorial vulnerability and the distribution of the local community opposition to the development of industrial facilities, energy technologies and transport infrastructures. Data about protests, surveyed by the Italian Permanent Media Observatory of Nimby Forum, indicate that territorial disputes effectively arise in the most industrialized and urbanized regions.

The geographical distribution of local opposition has been determined by an empirical analysis based on the overlay mapping of different informative layers.

The vulnerability assessment combined with the spatial analysis of disputes highlights the criticism of the complex decision-making processes and suggests relevant insights for better understanding the reasons for local opposition. For instance, the identification of the costs and benefits of new facilities depends on their size and scope. Consequently, the number of stakeholders involved is generally affected by the territorial level adopted for vulnerability assessment.

This paper is divided into three parts. The first part focuses on the methodology for measuring the territorial vulnerability. The second part displays the territorial vulnerability profile of Lombardy provinces with radar charts and vulnerability maps. The third part is dedicated to the analysis of the emerging issues by a territorial vulnerability assessment combined with a spatial analysis of local conflicts. The overlay mapping of the vulnerability index and the localization of oppositions, although empirical, represents an interesting investigation about the reasons for the disputes.

\section{Materials and methods}

\section{The definition of the Vulnerability Index}

The Vulnerability Index (VI) has been calculated according to the method developed by Toro et al. (2011) because it considers both the environmental and socio-economic variables.

The VI is given by the sum of the vulnerability value of each of the following criteria:

$V I=I_{W D}+I_{F D}+I_{L U C}+I_{S W Q}+I_{A Q}+I_{S S}+I_{P p}+I_{E_{p}}+I_{E d u}$

where $I_{W H}$ is the vulnerability value of wildlife habitat; $I_{W H}$ of the flora diversity; $I_{L U C}$ of the land use change; $I_{S W Q}$ of the surface water quality; $I_{A Q}$ of the air quality; $I_{E p}$ of the employment; $I_{P p}$ of the population; $I_{E d u}$ of the educational system; $I_{W H}$ of the social security. The vulnerability value at the level of criteria is normalized on the basis of the minimum and the maximum value of each variable according to the following formula:

$N_{i}=\left(X_{i}-X_{\min }\right) /\left(X_{\max }-X_{\min }\right)$

where $N_{i}$ is the normalized data, $X_{i}$ is the data to be normalized, $X_{\min }$ is the minimum value assumed by the variables and $X_{\max }$ is the maximum one. Because each criterion has the same importance in 


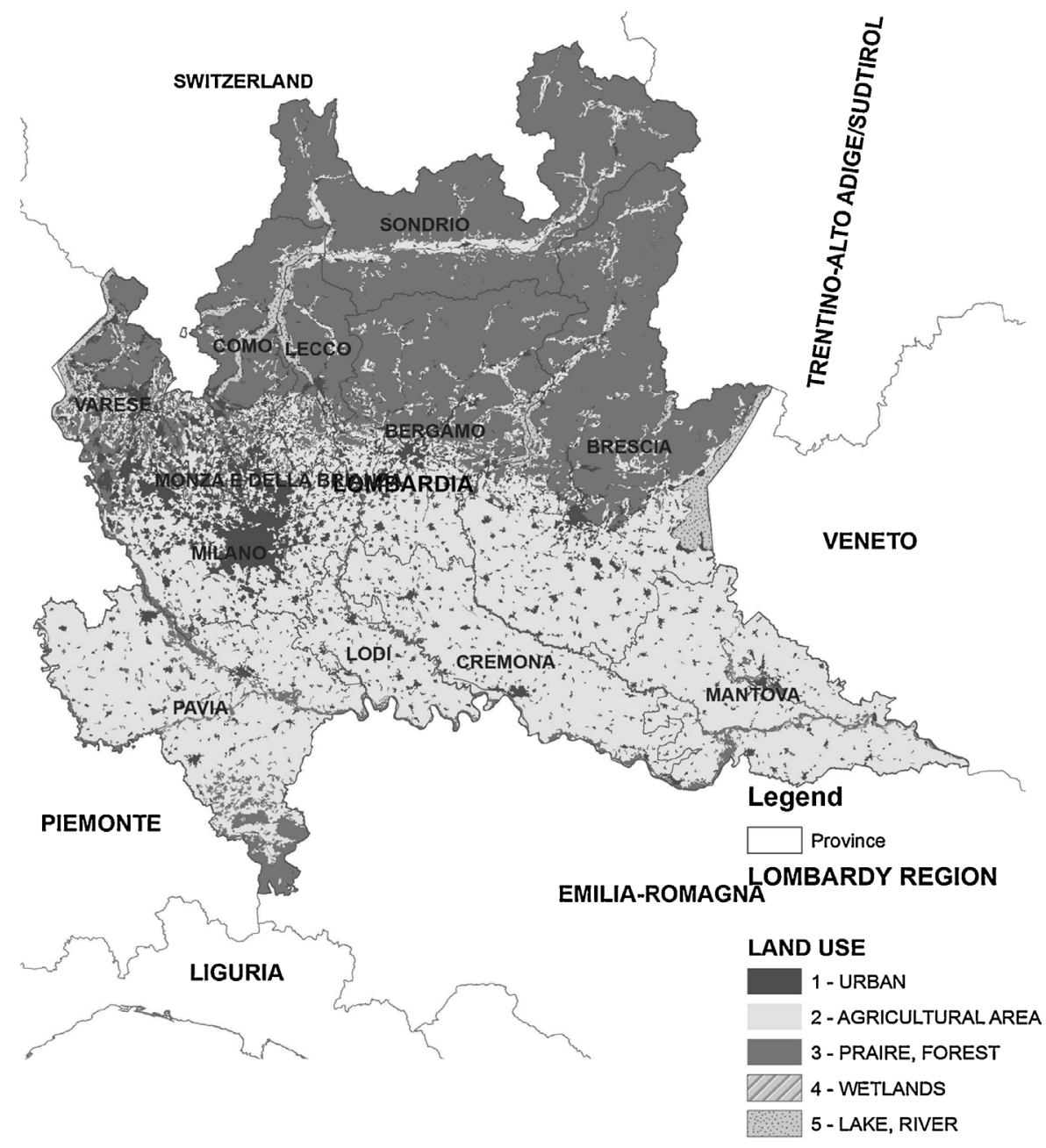

Fig. 1. Lombardy region; Land use, Provinces, Neighbouring territories.

the current step of the research, the values of the index reflect the level of vulnerability of each factor with reference to a neutral scenario. It should be relevant to introduce a weighting system for the criteria on the basis of both the technical analysis of the strengths and weaknesses of a specific territory and the involvement of local communities.

The analysis has focused on Lombardy, as it is one of the Italian regions with the highest amount of local community opposition in the last ten years as measured by the Nimby Forum annual survey. Given the subdivision of the country into three administrative levels (Regions, Provinces and Municipalities), the VI has been performed at the province level because the majority of the conflicts refer to linear (e.g., road infrastructure and high-voltage lines) or punctual (e.g., airport infrastructure, industrial plants, and biogas plants) development proposals that have an impact on the sub-regional territorial scale, for example, the provinces.

\section{Case study: the Lombardy region}

The Lombardy region has a surface of $23,858 \mathrm{~km}^{2}$ and a population of $9,400,000$ inhabitants (RDP, 2007). Nearly $50 \%$ of the regional territory is low lying, more than $40 \%$ is mountainous, and the rest is hilly (Fig. 1). Rural areas cover $82 \%$ of the territory and are inhabited by $35 \%$ of the population. Regional population density is 408 inhabitants $/ \mathrm{km}^{2}$, much greater than the national average $\left(199 \mathrm{ab} / \mathrm{km}^{2}\right)$ (Corsi, 2009). The demographical structure is affected by a declining birth rate and an increasing life expectancy, and 53\% of the regional adult population has a complete education (uppersecondary and superior). This percentage increases to $73 \%$ amongst young people. The Lombardy region generates more than $20 \%$ of the Italian GDP. The economic structure of Lombardy is characterized by the importance of the secondary and tertiary sector. In 2003, the GDP per capita was 28,254 euro (40\% more than the national average).

Nearly $57 \%$ of the regional territory is dedicated to the primary sector, while the total UAA covers $43 \%$ of it.

A portion of $15 \%$ of the regional territory falls under Natura 2000 , with a total surface of approximately $370,000 \mathrm{Ha}$ and 245 sites, and there are 92 parks and other protected areas that cover 131,000 Ha (Fig. 2). Urban and peri-urban areas have a great importance in terms of population (more than 5.9 million people) and surface and have a density of nearly 1400 inhabitants $/ \mathrm{km}^{2}$. The Lombardy region holds, together with the Veneto region, the primacy of the urbanized land that affects $13 \%$ of the total area (ISTAT, 2013). The urban area is made up of the main towns (Bergamo, Brescia, Monza and Brianza) and the large conurbation of Milan. The Lombardy region is crossed by one of the largest networks of infrastructure in Italy: The rail network is extensive, with $80.6 \mathrm{~km}$ per $1000 \mathrm{~km}^{2}$ (Corsi, 2009); the road network is just under $12,000 \mathrm{~km}$ and represents $7.9 \%$ of the national road network (Annuario Statistico Regionale, 2011). In the region, there are also 14 airports, of which 5 are for civilian use (Annuario Statistico Regionale, 2007). In the Lombardy region, 7 landfills (ISPRA, 2012) and 13 waste-to-energy plants (ARPA Lombardia, 2010) are active. Of the Italian biogas 


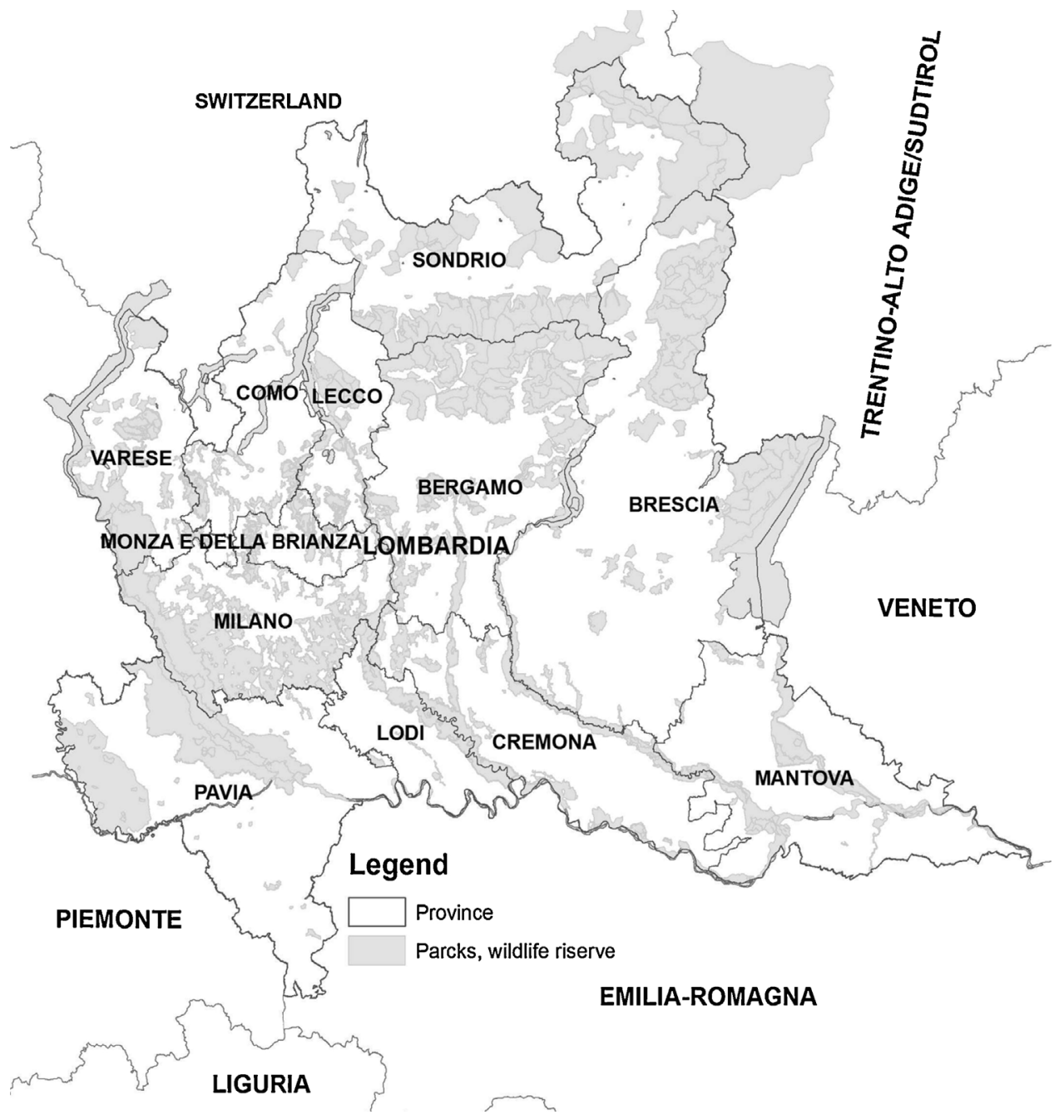

Fig. 2. Lombardy region: Protected areas, Parks, Reserves.

Source: Aree protette della Regione Lombardia (2013).

plants, 37.6\% are present in Lombardy (CRPA, 2013). The SIRENA project in the Lombardy region has identified approximately 24,000 power plants ranging from hydroelectric plants to photovoltaic power (the most numerous) to plant biomass in power plants (FINLOMBARDIA, 2012). In 2012, the Authority for Electricity and Gas measured in the Lombardy region $127,348 \mathrm{~km}$ of electricity distribution networks, more than all other regions (Autorità per l'energia elettrica e il gas, 2012).

The Vulnerability Index (VI) has been structured through the measurement of environmental and socio economic criteria, quantified by specific criteria as suggested by the above-mentioned research by Toro (see Table 1 ).

Table 1

Vulnerability criteria.

\begin{tabular}{|c|c|c|c|c|}
\hline Criteria & Acronym & Indicators & Sources & Year \\
\hline Wildlife Diversity & WD & Number of threatened species & $\begin{array}{l}\text { Centro Flora Autoctona } \\
\text { (Lombardy Region) }\end{array}$ & 2008 \\
\hline Flora Diversity & FD & Number of threatened species & $\begin{array}{l}\text { Centro Flora Autoctona } \\
\text { (Lombardy Region) }\end{array}$ & 2008 \\
\hline Air Quality & AQ & Air Quality Index & $\begin{array}{l}\text { ARPA Lombardia: Regional } \\
\text { agency for environmental } \\
\text { protection }\end{array}$ & 2011 \\
\hline Land use & LUC & Percentage of natural areas & $\begin{array}{l}\text { DUSAF } 2.1 \text { (Destination of Use } \\
\text { of Agricultural and Forest Soils) } \\
\text { Lombardy Region }\end{array}$ & 2010 \\
\hline Surface Water Quality & SWQ & $\begin{array}{l}\text { Sewage treatment channelled } \\
\text { into the drainage system }\end{array}$ & $\begin{array}{l}\text { ATO (Ambito Territoriale } \\
\text { Ottimale) Lombardy Region }\end{array}$ & 2007 \\
\hline Social Security & SS & Quality of Life Index & ILSOLE24ORE (annual survey) & 2012 \\
\hline Population & $\mathrm{Pp}$ & Population density & ISTAT (population survey) & 2013 \\
\hline Employment & Ep & Unemployment rate & ISTAT (labour force survey) & 2012 \\
\hline Education system & Edu & $\begin{array}{l}\text { Average years of education of } \\
\text { the population over } 15 \text { years }\end{array}$ & ISTAT (population census) & 2001 \\
\hline
\end{tabular}




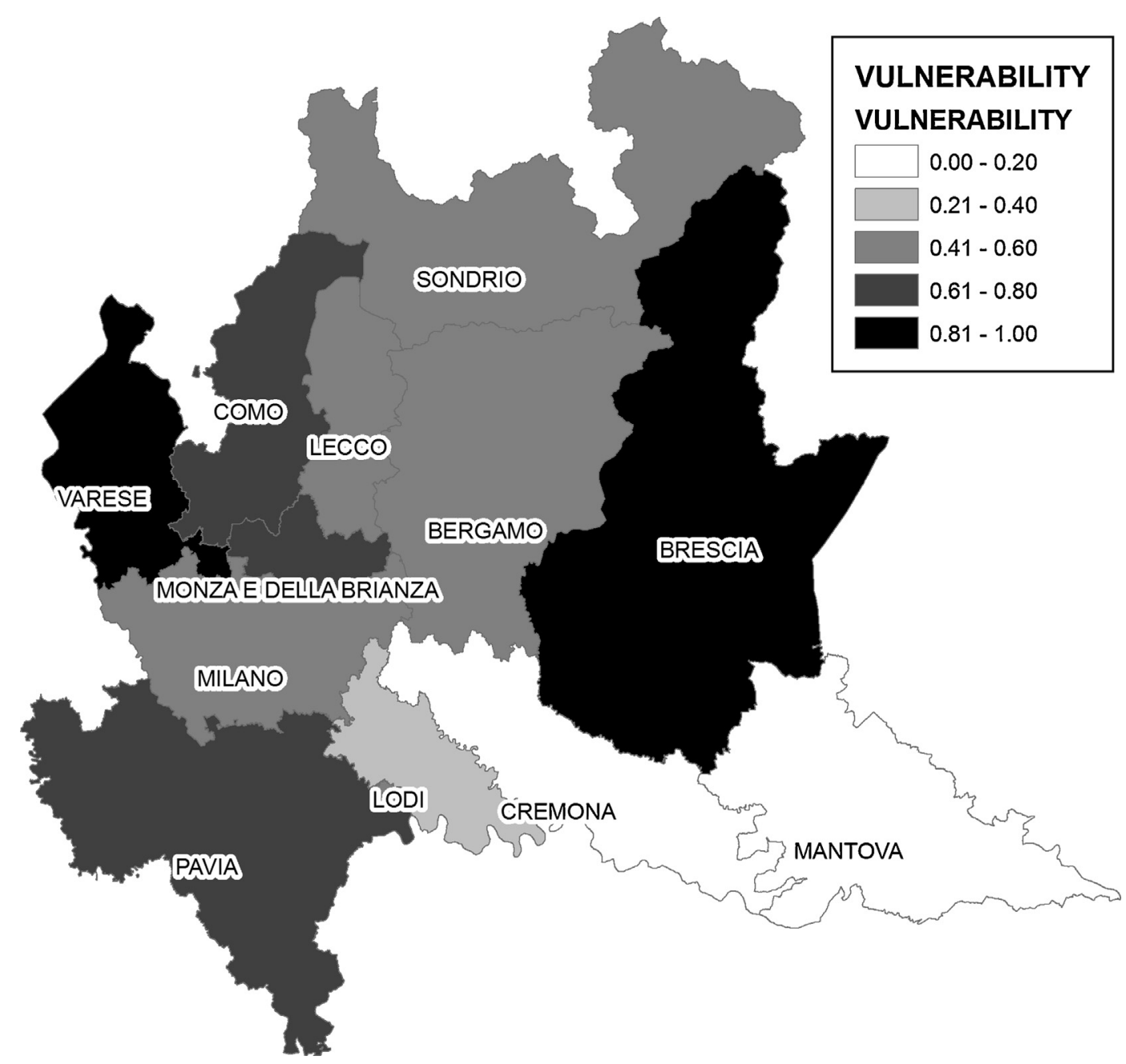

Fig. 3. The Vulnerability map of each province.

A short summary of the criteria is provided afterward.

Regarding Wildlife Diversity (WD) and Flora Diversity (FD), the Regional Law No. 10 of March 2008 allows the specification and quantification of endangered species at the provincial level. The regulation lists the fauna and flora that are threatened. The range of threatened species has been tested and identified by the Regional Centre of Monte Barro Autochthonous Flora Centre (CFA). CFA is an experimental station of the Lombardy region the fundamental objective of which is to promote actions that ensure the availability of native plants compatible with the Lombardy territory. The species for which in recent years there has been no certainty regarding their existence have not been included in the study (CFA, 2008).

The Air Quality (AQ) index has been calculated on the basis of a partial value for each of the following air pollutants: PM10, carbon monoxide $(\mathrm{CO})$, nitrogen dioxide $\left(\mathrm{NO}_{2}\right)$, sulfur dioxide $\left(\mathrm{SO}_{2}\right)$ and ozone $\left(\mathrm{O}_{3}\right)$. Thus, the Air Quality index has been measured by the following equation:

$\mathrm{AQ}=\frac{100 \times \mathrm{PC}}{\mathrm{PL}}$

where $\mathrm{AQ}=$ Air Quality index, $\mathrm{PC}=$ concentration of the pollutant, and $\mathrm{PL}=$ the permissible limit of the pollutant.

The approach adopted in the case study is based on the allocation to the AQ of the lowest sub-index value that has been adopted (EPA, 2009), as it is the most widely used approach in the international literature, mainly in the field of forecasts. The data required for the calculation of the Air Quality index were collected and analyzed using the monitoring stations of ARPA Lombardia (ARPA, 2011), the Regional Agency for Environmental Protection.

The Land Use (LUC) of the study area has been assessed through the DUSAF 2.1 and Corine Land Cover database, which allow identifying and monitoring the characteristics of land cover and use. The territory is articulated and represented by 5 main classes (Class 1 : Artificial areas, Class 2: Rural territories, Class 3: Forests and natural areas, Class 4: Wetlands, Class 5: Water Bodies). The percentage of natural soil in this study has been calculated for each province. The five above-mentioned classes have been combined with reference to the degree of the soil naturalness, defined by the presence of human activities and the consequent modification of the territory in comparison to its original and natural condition.

The following 3 classes derive from the combination of the five previous:

- Populated areas (Class 1): areas where human presence has drastically changed the original layout of the area.

- Seminatural areas (Class 2): agricultural areas where intensive cultivation of the soil prevails over the natural component.

- Natural Areas (Class 3, 4, 5): areas that are the closest to the natural condition of the land. In these areas, it is expected that biodiversity is high.

The Surface Water Quality (SWQ) has been evaluated on the basis of how the waste water is purified and channelled into the 


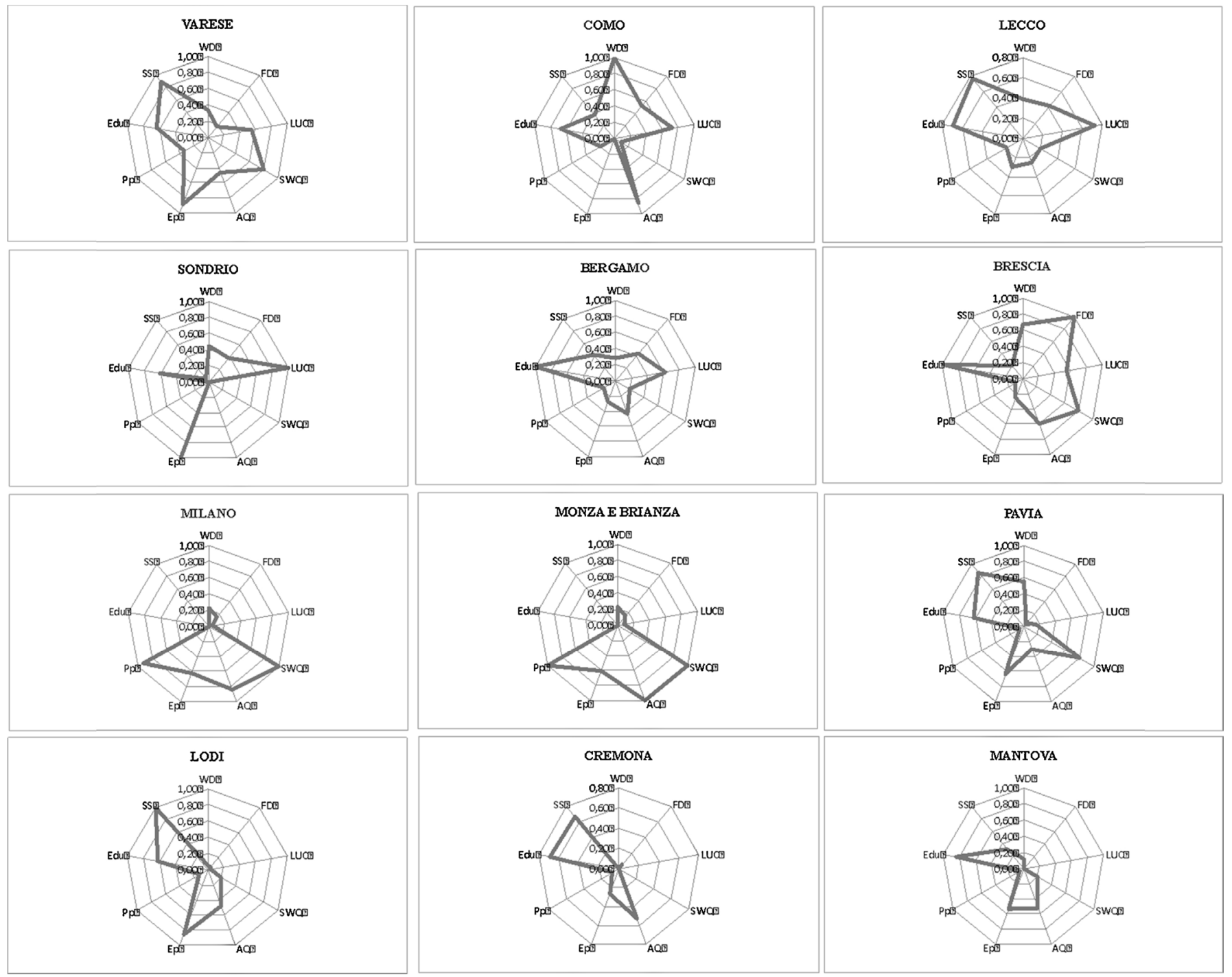

Fig. 4. Level of vulnerability for each environmental and socio-economic factor at the province level.

drainage system at the provincial level (according to the classification of the coverage of sewerage services in the environmental authorities - the ATO or Ambito Territoriale Ottimale - that manage public services such as water and waste disposal). The method of purification is applied to all municipalities with more than 2000 inhabitant equivalents. The data of the municipalities that belong to a province were collected for a given provincial water quality. The degree of waste treatment is a percentage of the provincial load.
The data extracted by the First Report on Infrastructure (Regione Lombardia, 2008) refer to the year 2007.

Social Security (SS) has been considered for the Quality of Life Index, calculated every year by Il Sole 24 Ore, an Italian financial daily, for all of the Italian provinces on the basis of six thematic areas (the standard of living, service to people and environment, business and labour, public order, population, facilities and activities for leisure).

Table 2

Measurement of the vulnerability value of each criterion.

\begin{tabular}{|c|c|c|c|c|c|c|c|c|c|}
\hline Provinces & WD & FD & AQ & LUC & SWQ & SS & $\mathrm{Pp}$ & Ep & Edu \\
\hline VARESE & 0.33 & 0.17 & 0.46 & 0.56 & 0.80 & 0.89 & 0.33 & 0.88 & 0.64 \\
\hline COMO & 1.00 & 0.53 & 0.85 & 0.73 & 0.10 & 0.38 & 0.20 & 0.00 & 0.67 \\
\hline LECCO & 0.39 & 0.42 & 0.26 & 0.73 & 0.20 & 0.77 & 0.18 & 0.30 & 0.70 \\
\hline SONDRIO & 0.44 & 0.38 & 0.00 & 1.00 & 0.00 & 0.05 & 0.00 & 1.00 & 0.62 \\
\hline BERGAMO & 0.28 & 0.43 & 0.43 & 0.62 & 0.20 & 0.41 & 0.17 & 0.28 & 1.00 \\
\hline BRESCIA & 0.67 & 1.00 & 0.59 & 0.56 & 0.80 & 0.21 & 0.10 & 0.25 & 0.99 \\
\hline MILANO & 0.22 & 0.15 & 0.84 & 0.05 & 1.00 & 0.00 & 0.93 & 0.62 & 0.00 \\
\hline MONZA E BRIANZA & 0.22 & 0.15 & 1.00 & 0.09 & 1.00 & 0.00 & 1.00 & 0.61 & 0.00 \\
\hline PAVIA & 0.56 & 0.05 & 0.31 & 0.15 & 0.80 & 0.86 & 0.06 & 0.63 & 0.63 \\
\hline LODI & 0.06 & 0.05 & 0.48 & 0.03 & 0.20 & 1.00 & 0.11 & 0.85 & 0.62 \\
\hline CREMONA & 0.00 & 0.05 & 0.53 & 0.00 & 0.00 & 0.67 & 0.07 & 0.26 & 0.69 \\
\hline MANTOVA & 0.11 & 0.00 & 0.52 & 0.00 & 0.20 & 0.32 & 0.06 & 0.53 & 0.84 \\
\hline
\end{tabular}


The indicator for Population (Pp) is density (ISTAT, 2012). Density indicates the number of inhabitants living in a given area; in our case, the reference unit is the province. The measure is expressed in inhabitants per square kilometre (inhab. $/ \mathrm{km}^{2}$ ).

The unemployment rate (Ep) has been defined as the ratio between the population aged 15 and above who are in search of employment. The ISTAT Labour Force Survey is the main source of statistical information on the labour market. The data refer to the year 2012.

The indicator for Education system (Edu) has been calculated as the percentage of residents with qualifications of secondary school and beyond (ISTAT, 2001).

Table 2 displays the vulnerability values for each criteria at the province level in the Lombardy region.

The outputs of the vulnerability assessment have been organized into thematic maps for the purpose of providing a comprehensive overview of the environmental and socioeconomic state of the Lombardy region (see Fig. 3).

\section{Results}

As represented by Graph 1, the majority of the provinces have a VI value that is above the average. In the higher positions of the rank, there are the provinces of Brescia $(\mathrm{VI}=1)$ and Varese $(\mathrm{VI}=0.96)$, while in the lower positions, there are Lodi $(\mathrm{VI}=0.39)$, Mantova $(\mathrm{VI}=0.11)$ and Cremona $(\mathrm{VI}=0)$. The others exhibit values that range from 0.42 to 0.62 (Sondrio, Milano, Bergamo, Lecco, Monza e Brianza, Pavia).

Although the distribution of values appears quite homogeneous, the analysis of each vulnerability criteria indicates a varied picture. The radar charts highlight the weakness and strengths of each province and their degree of intensity (see Fig. 4). Apart from the two clusters of provinces - Mantova/Cremona/Lodi and Milano/Monza Brianza - for which the vulnerability interests exhibit the same axis with a comparable level of importance, the different shape assumed by the radar charts of the other provinces reveals the peculiarity of the territory analyzed (see Fig. 4).

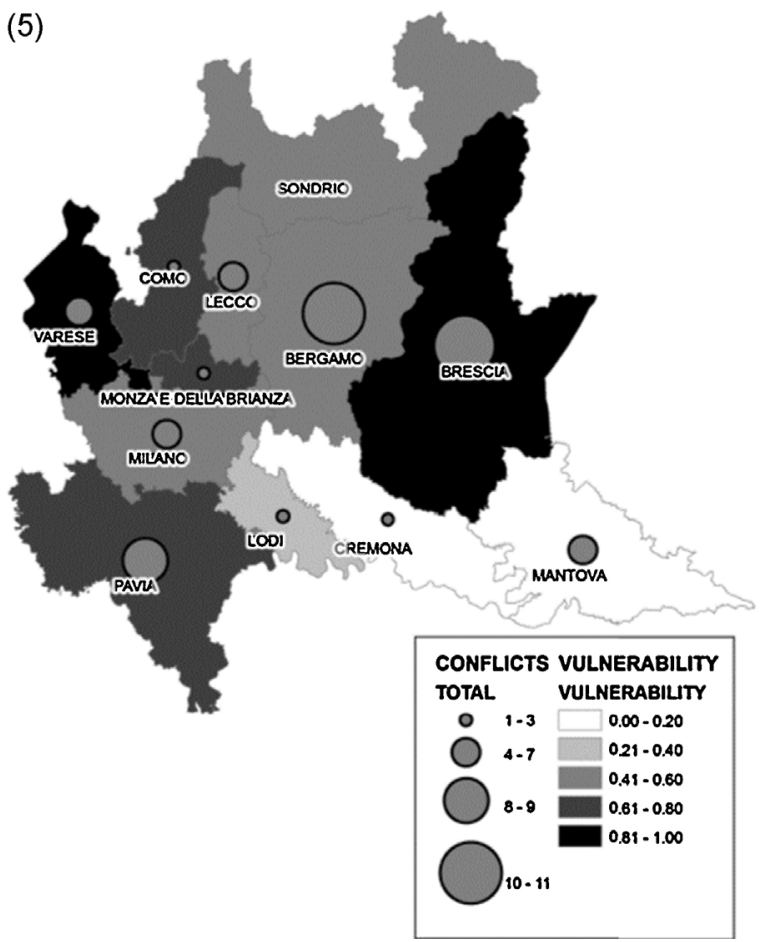

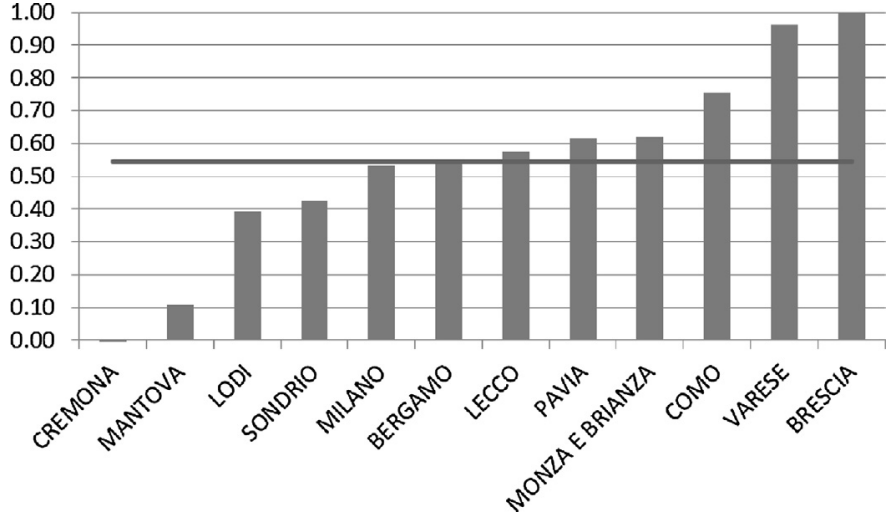

Graph 1. The Vulnerability Index in each province of the Lombardy region. The black line indicates the average value of the VI (0.54).

In the majority of the provinces, the vulnerability is higher for the group of environmental factors (WD, FD, LUC, SWQ AQ) than for the socio-economic ones (Ep, Pp, Edu, SS), except for the provinces of Lodi, Mantova and Cremona, although the rural areas are an important presence.

Furthermore, as the Land Use criterion takes into account the percentage of natural areas, the vulnerability assessment neglects that a great part of those provinces is occupied by intensive agriculture, which should be considered as much as the vulnerability factor (Mazzocchi et al., 2013). Mountain areas (for instance, in the province of Sondrio), as well as the agricultural lands, seem much less vulnerable than highly urbanized provinces. Agricultural areas are not subject to a special protection. Only a few specific areas are included in agricultural parks (e.g., the South Milan Agricultural Park), which do not have the level of protection of natural parks and therefore do not affect the VI; however, this definition could lead the policymakers to identify them as potential areas of development and therefore as a suitable location for plants and infrastructure.
(6)

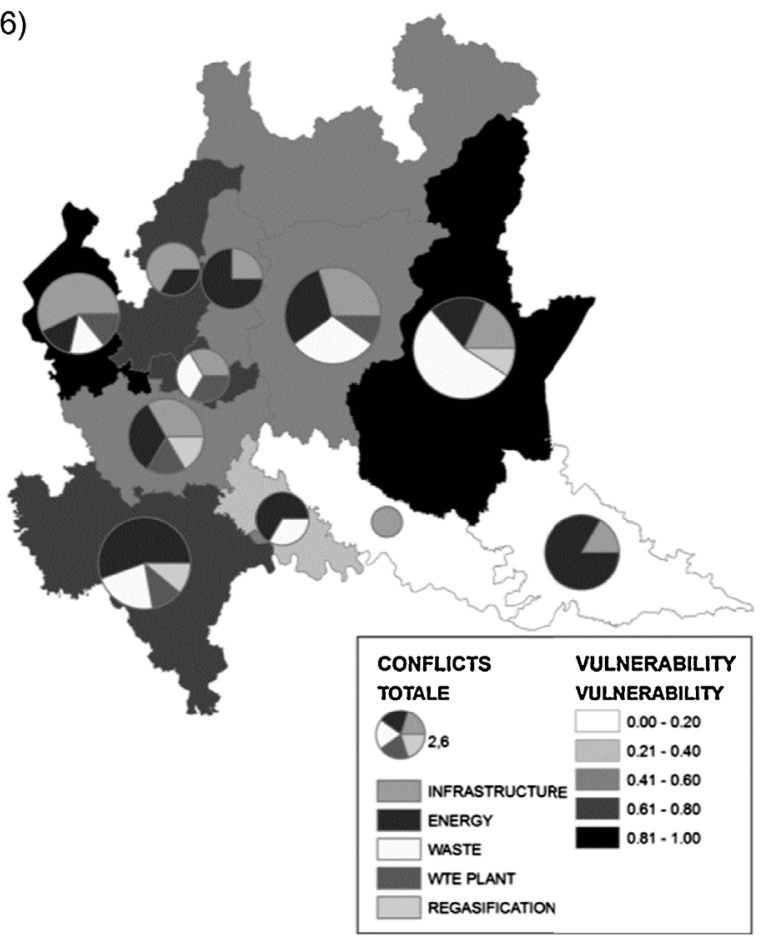

Figs. 5 and 6. Number of local conflicts and degree of vulnerability. Typologies of conflicts and degree of vulnerability. 
Therefore, the vulnerability value of the Land Use criterion, even if equal, does not have the same meaning for all of the provinces. This is a pitfall of the assessment methodology that should be solved for the purpose of providing more robust results.

In addition to the degree of vulnerability at the province level, local conflicts caused by the development of new infrastructure and plants have been considered (Nimby ${ }^{\circledR}$ Forum report 2012).

Through a system of media monitoring, the Permanent Media Observatory of the Nimby Forum surveys the news related to territorial disputes, and it creates an inventory of the plants under opposition. The data are analyzed and discussed, providing an updated overview of the phenomenon and an annual report.

The latest Nimby ${ }^{\circledR}$ Forum report indicates that in 2012, the number of plants and infrastructures contested at the national level is 354 (nearly $7 \%$ higher than in the previous edition). In the Lombardy region, there are 54 disputes against new facilities (infrastructure, power plants, pipelines, landfill or biogas plants and other).

To explore the relationship between conflicts and vulnerability, the opposition has been grouped into 5 categories (1. Infrastructure: mainly highways, ring roads and roads, as well as the expansion of the airport of Malpensa; 2. Energy plants: power plants and high voltage lines; 3 . Waste landfills, centres for the treatment of special waste included; 4 . Incinerators; 5. LNG terminals) and overlaid on the vulnerability maps.

As indicated by Figs. 5 and 6, the maps provide a means of: i) putting forward a hypothesis about the conflicts that have emerged around the localization of new facilities and the vulnerability of the Lombardy region assessed at the province level; ii) addressing questions regarding the driving factors of vulnerability in different provinces; iii) and investigating the degree to which the oppositions depends on the effective territorial vulnerability.

The analysis of the vulnerability combined with the spatial distribution of local conflicts indicates a relationship between the value of general vulnerability (VI) and the number of oppositions. More precisely, the provinces of Brescia and Varese, for which the VI value is 1 and 0.96 , respectively, with a prevalence of environmental vulnerability, reveal the higher number of oppositions (10-11) than the province of Bergamo, for which the VI value is 0.54. A lower number of conflicts is observed in the provinces of Sondrio (VI=0.42), Lodi $(\mathrm{VI}=0.39)$, Cremona $(\mathrm{VI}=0.11)$ and Mantova $(\mathrm{VI}=0)$. Conflicts due to opposition to infrastructure and electrical systems are the most popular among the provinces of the Lombardy region. Other typologies of conflicts do not seem to be influenced by the degree of vulnerability (Fig. 6).

\section{Discussion and conclusions}

The first outputs of this research indicate that the VI provides a functional classification of the territories. It could effectively be used to improve decisions about the development of facilities and to fairly distribute the costs and benefits both among public interest and private profit and among present and future generations. The synthetic information given by the VI makes it possible to compare and rank different territories according to their degree of environmental and socio-economic vulnerability. The vulnerability maps represent additional knowledge that planners should use for better understanding the basis of local conflicts. At the same time, they can be considered a neutral scenario, which the impacts caused by the new facilities might change.

With regard to the location of the conflicts, significant differences are not detectable, but the spread of local opposition corresponds to a low willingness of the community to accept a change in their utility due to the changes in land use that cause negative externalities.
Although the conflicts should be proportional to the degree of territorial vulnerability as has been posited by the research question, the outputs of this analysis deny this assumption. Local disputes seem not to be affected by vulnerability and risk. Furthermore, it must be taken into consideration that this type of proportional relationship has not emerged because the Nimby Forum database does not analyze the risk for each typology of the facilities and consequently the risk perception. Nevertheless, it is well acknowledged that there is substantial variation among the individual perceptions of impacts, such as the environmental and health impacts and the effects on property values and public safety (Schively, 2007).

Future developments in the research will require balancing the conflict importance according to the degree of the specific risk of the different infrastructures and plants under opposition.

Finally, if the criteria and indicators that constitute the index are widely shared and supported by the literature, weighting is a subject of more attention. The results discussed in this paper have not deliberately contemplated the weighting of the VI. The weight assignment could support the analysis of the state of a territory in a more dynamic way by taking into account the effects of policy measures regarding facility development with the aid of vulnerability assessment. The weighting system should be defined, on the one hand, by the measurement of the specific risk, as already described, and, on the other hand, by the involvement of local communities and stakeholders. The public engagement in the decision-making processes could be envisaged as an opportunity to spread knowledge and awareness about the vulnerability of the territories. Involving the perceptions and priorities of the public before the definition of the development options could prevent the adverse positions taken against future projects that are viewed as unfair and unequal. From this perspective, an understanding of territorial vulnerability, grounded in environmental, economic and social criteria, would seem to help define the alternative projects before the decision-making process has begun.

\section{References}

Barde, J.P., Gerelli, E., 1980. Economia e Politica dell'ambiente. Il Mulino, Bologna Berry, P.R., Rounsevell, H.P., Audsley, E., 2006. Assessing the vulnerability of agricultural land use and species to climate change. Environ. Sci. Policy 9, 189-204.

Boulding, K.E., 1966. The Economics of the Coming Spaceship Earth. In: Jarret, H. (Ed.), Environmental Quality in a growing Economy, Resources for the Future. Johns Hopkins University Press, Baltimore (MD), pp. 3-14.

Bradley, M., Smith, E., 2004. Using science to assess environmental vulnerabilities. Environ. Monit. Assess. 94, 1-7.

Corsi, S., 2009. Infrastrutture viarie e agricoltura. In: AAVV (Ed.), Per un'altra campagna, Riflessioni e proposte sull'agricoltura periurbana. Milano, Maggioli, pp. 51-59.

Costanza, R., d'Arge, R., de Groot, R., Farber, S., Grasso, M., Hannon, B., Limburg, K., Naeem, S., O’Neill, R.V., Paruelo, J., Raskin, R.G., Sutton, P., Van den Belt, M., 1997. The value of the world's ecosystem services and natural capital. Nature $387,253-260$.

Cutter, S., Boruff, B., Shirley, W., 2003. Social vulnerability to environmental hazards. Soc. Sci. Quart. 84, 242-261.

Cutter, S., Mitchell, J.T., Scott, M.S., 2000. Revealing the Vulnerability of People and Places: A Case Study of Georgetown County South Carolina. Ann. Assoc. Am. Geographers 90 (4), 713-737.

Cutter, S.L., Emrich, C.T., Webb, J.J., Morath, D., 2009. Social Vulnerability to Climate Variability Hazards: A Review of the Literature. Final Report to Oxfam America. Hazards and Vulnerability Research Institute, Department of Geography, University of South Carolina, pp. 1-44.

Darly, S., Torre, A., 2013. Conflicts over farmland uses and the dynamics of "agriurban" localities in the Greater Paris Region: an empirical analysis based on daily Regional press and field interviews. Land Use Policy 33, 90-99.

De Groot, R.S., Wilson, M.A., Boumans, R.M.J., 2002. A typology for the classification, description and valuation of ecosystem functions, goods and services. Ecol. Econ. 41, 393-408.

Golobič, M., Breskvar Žaucery, L., 2010. Landscape planning and vulnerability assessment in the Mediterranean. Final report. Regional Activity Centre for the Priority Actions Programme.

Hessel, R., Van den Berg, J., Kaboréc, O., Van Kekema, A., Verzandvoorta, S., Dipamad, J., Dialloe, B., 2009. Linking participatory and GIS-based land use planning methods: A case study from Burkina Faso. Land Use Policy 26, 1162-1172. 
Hilson, G., 2002. An overview of land use conflicts in mining communities. Land Use Policy 19, 65-73.

Kamruzzaman, Md., Baker, D., 2013. Will the application of spatial multi criteria evaluation technique enhance the quality of decision-making to resolve boundary conflicts in the Philippines. Land Use Policy 34, 11-26.

Legislative Decree No. 81 of 2008 Implementation of Article 1 of the Law of 3 August 2007, n. 123, concerning the protection of health and safety in the workplace.

Lindgren, F., Johansson, B., Malmlöf, T., Lindvall, F., 2013. Siting conflicts between wind power and military aviation: problems and potential solutions. Land Use Policy 34, 104-111.

Magsi, H., Torre, A., 2013. Proximity analysis of inefficient practices and socio-spatial negligence: evidence, evaluations and recommendations drawn from the construction of Chotiari reservoir in Pakistan. Land Use Policy 36, 567-576.

Mattia, S., Oppio, A., 2008. Pratiche di cittadinanza attive: il bilancio partecipativo. $6^{\circ}$ Rapporto sul processo di liberalizzazione della società italiana. Franco Angeli, Milano, pp. 81-104.

Mazzocchi, C., Sali, G., Corsi, S., 2013. Land use conversion in metropolitan areas and the permanence of agriculture: Sensitivity Index of Agricultural Land (SIAL), a tool for territorial analysis. Land Use Policy 35, 155-162.

Menoni, S., Margottini, C., Galderisi, A., Delmonaco, G., Ferrara, F., Kropp, J.P., Esteban, J.F., Lopez, J., Pugliano, A., Mejri, O., 2011. Shift in thinking. In: Menoni, S., Margottini, C. (Eds.), Inside risk: A strategy for Sustainable Risk Mitigation. Springer-Verlag, Milano, pp. 287-327.

Menoni, S., Molinari, D., Parker, D., Ballio, F., Tapsell, S., 2012. Assessing multifaceted vulnerability and resilience in order to design risk-mitigation strategies. Nat. Hazards 64, 2057-2082.

Metzger, M., Rounsevell, M., Acosta-Michlik, L., Leemans, R., Schröter, D., 2006. The vulnerability of ecosystem services to land use change. Agric. Ecosyst. Environ. $114,69-85$.

Mishan, E., 1965. Relections on a recent development in the concept of external effects. Can. J. Political Econ. 31, 3-34.

Ndubisi, F., 2002. Ecological Planning: A Historical and Comparative Synthesis. Johns Hopkins University Press, Baltimore.

Nijnik, M., Zahvoyska, L., Nijnik, A., Ode, A., 2009. Public evaluation of landscape content and change: several examples from Europe. Land Use Policy 26, 77-86.

Pigou, A.C., 1948. The Economics of Wellfare. McMillan, London.

Rauschmayer, F., Wittmer, H., 2006. Evaluating deliberative and analytical methods for the resolution of environmental conflicts. Land Use Policy 23, 108-122.

Roegen, G., 1971. The Entropy Law and the Economic Process. Harvard University Press, Cambridge.

Saarikoskia, H., Raitio, K., Barry, J., 2013. Understanding 'successful' conflict resolution: policy regime changes and new interactive arenas in the Great Bear Rainforest. Land Use Policy 32, 271-280.

Schively, C., 2007. Understanding the NIMBY and LULU phenomena: reassessing our knowledge base and informing future research. J. Plan. Literature 21 (3), 255-266.

Smith, E.R., Mehaffey, M.H., O’Neill, R.V., Wade, T.G., Kilaru, J.V., Tran, L., 2008. Guidelines to Assessing Regional Vulnerabilities. Environmental Protection Agency, Washington, DC

Toro, J., Duarte, O., Requena, I., Zamorano, M., 2011. Determining Vulnerability Importance in Environmental Impact Assessment. The case of Colombia. Environ. Impact Assessment Rev. 32, 107-117.

Torre, A., Melot, R., Magsi, H., Bossuet, L., Cadoret, A., Caron, A., Darly, S., Jeanneaux, P., Kirat, T., Vu Pham, H., Kolokouris, O., 2014. Identifying and measuring land-use and proximity conflicts: methods and identification. SpringerPlus 3 (85), 1-26 http://www.springerplus.com/content/3/1/85

Tran, L., O’Neill, R., Smith, E., 2010. Spatial pattern of environmental vulnerability assessment in the Mid-Atlantic Region, USA. Appl. Geogr. 30, 191-202.

Turner, B., Matson, P., McCarthy, J., Corell, R., Christensen, L., Eckley, N., HovelsrudBroda, G., 2003. A framework for vulnerability analysis in sustainability science. Proc. Natl. Acad. Sci. U.S.A. 100, 8074-8079.
Wittmer, H., Rauschmayer, F., Klauer, B., 2006. How to select instruments for the resolution of environmental conflicts? Land Use Policy 23, 1-9.

\section{Web references}

Annuario Statistico Regionale, 2007, Retrieved 26/06/2014 from: http://www. asr-lombardia.it/ASR/trasporti/reti-infrastrutturali-e-impianti/lombardia-eprovince/tavole/3010/.

Annuario Statistico Regionale, 2011, Retrieved 26/06/2014 from: http://www. asr-lombardia.it/ASR/trasporti/reti-infrastrutturali-e-impianti/regioni-italiane/ tavole/1679/.

Aree Protette della Regione Lombardia, 2013, Retrieved 30/04/2014 from: http://www.cartografia.regione.lombardia.it/geoportale/DiscoveryServlet? command=viewdetails\&uuid $=\{1$ F3EC07C $-75 F D-172 C-73 D 7-A 5 B F 7217 B 768\}$

ARPA Lombardia, 2011, Retrieved 13/03/2014 from: http://www2.arpalombardia. it/siti/arpalombardia/meteo/richiesta-dati-misurati/Pagine/ RichiestaDatiMisurati.aspx.

ATO Ambito Territoriale Ottimale, Regione Lombardia, 2007, Retrieved 31/10/2014 from: http://www.reti.regione.lombardia.it/cs/Satellite?c= Redazionale_P\&childpagename=DG_Reti\%2FDetail\&cid=1213566061277\& packedargs=NoSlotForSitePlan\%3Dtrue\%26menu-to-render\% 3D1213422387490\&pagename=DG_RSSWrapper.

Autorità per l'energia elettrica e il gas, 2012, Retrieved 25/06/2014 from: http://www.autorita.energia.it/it/dati/elenco_dati.htm.

Centro Flora Autoctona, Flora e piccola Fauna protette in Lombardia, 2008, Regione Lombardia Retrieved 13/03/2014 from: http://www.parcobarro. lombardia.it/_lr10/index.php?title=Pagina_principale.

CRPA, Biogas: Il settore è strutturato e continua a crescere, 2013, L'informatore Agrario 2013 Retrieved 31/10/2014 from: http://crpalab. crpa.it/media/documents/crpa_www/Settori/Ambiente/Download/Archivio_ 2013/IA_suppl11_2013_p11.pdf.

DUSAF 2.1, Uso del suolo in Regione Lombardia I dati DUSAF 2010, ERSAF Regione Lombardia, 2010, Retrieved 31/10/2014 from: http://www.ersaf lombardia.it/upload/ersaf/pubblicazioni/I dati Dusaf ed. 2010_13383_392.pdf.

EPA, United States Environmental Protection Agency, 2009. Air Quality Index - a Guide to Air Quality and your health. U.S. Environmental Protection Agency Office of Air Quality Planning and Standards Outreach and Information Division Research, Triangle Park, NC, Retrieved 26/06/2014 from: http://www.epa.gov/airnow/aqi_brochure_02_14.pdf.

FINLOMBARDIA, 2012. Retrieved 30/04/2014 from: http://sirena.finlombarda. it/sirena/catasto.jsp.

ILSOLE24ORE, 2012. Retrieved 13/03/2014 from: http://www.ilsole24ore com/speciali/qvita_2012/home.shtml.

ISPRA, 2012. Rapporto dei rifiuti urbani, Retrieved 30/04/2014 from: http://www. isprambiente.gov.it/files/pubblicazioni/rapporti/rifiuti2012/rapporto-rifiuti2012-estratto.pdf.

ISTAT, Labor force survey, 2012. Retrieved 13/03/2014 from: http://dati.istat.it/.

ISTAT population census, 2001, Retrieved 13/03/2014 from: http://dati.istat.it/

ISTAT population survey, 2013, Retrieved 13/03/2014 from: http://dati.istat.it/.

Millenium Ecosystem Assessment, 2005. Ecosystem and human wellbeing, Synthesis, Retrieved 10/03/2014 from http://www.millenniumassessment org/documents/document.356.aspx.pdf.

NIMBY FORUM, 2012. Gli Impianti contestati, Retrieved 19/03/2014 from: http://www.nimbyforum.it/.

RDP, Rural Development Programme 2007-2013 for Region Lombardia (Italy) - CCI N ${ }^{\circ}$ 2007IT06RPO007, 2007, Retrieved 13/03/2014 from: http://www. reterurale.it/.

Regione Lombardia, 2008. Rapporto sulle infrastrutture, Retrieved 31/10/2014 from http://www.ors.regione.lombardia.it/resources/pagina/N11e3b0be4ff4cb18119 /N11e3b0be4ff4cb18119/Rapporto_sulle_infrastrutture.pdf. 